\title{
Preparation of Modified Sulfonated Poly(styrene divinylbenzene) with Polyaniline as a New Polymer Electrolyte Membrane for Direct Methanol Fuel Cell
}

\author{
Valiollah Mandanipour ${ }^{1}$, Meissam Noroozifar ${ }^{1, *}$, Ali Reza Modarresi-Alam ${ }^{2}$ \\ ${ }^{1}$ Department of Applied Chemistry, University of Sistan and Baluchestan, Zahedan, P.O. Box 98155- \\ 674, Iran \\ ${ }^{2}$ Department of Chemistry, polymer research laboratory, University of Sistan and Baluchestan, \\ Zahedan, Iran \\ *E-mail: mnoroozifar@chem.usb.ac.ir
}

doi: $10.20964 / 2016.06 .32$

Received: 12 February 2016 / Accepted: 4 April 2016 / Published: 4 May 2016

\begin{abstract}
A new modified proton exchange membrane (PEM) has been prepared with polyaniline (PANI)sulfonated poly(styrene divinylbenzene) resin (SPSD)-polyethylene (PE). The proposed polymer electrolyte membranes (PEM), PANI- SPSD-PE were prepared by blending different ratios of PANI (1-5\%) with SPSD-PE and characterized with FT-IR, TGA/DSC and SEM. Different properties of PMEs such as; water uptake, resistance and, conductivity as well as methanol permeability were measured to evaluate its performance in a direct methanol fuel cell (DMFC). The on-set degradation temperature of the SPSD is above $120^{\circ} \mathrm{C}$. The ionic conductivity and permeability of the membrane for methanol were increased with increasing of PANI (\%) in the membrane and temperature without an extra humidity supply. Finally, a DMFC was designed and assembled with the suggested PANI-SPSDPE membrane.
\end{abstract}

Keywords: Polyaniline, Sulfonated poly(styrene divinylbenzene), PEM, DMFC, Polymer composites.

\section{$\underline{\text { FULL TEXT }}$}

(C) 2016 The Authors. Published by ESG (www.electrochemsci.org). This article is an open access article distributed under the terms and conditions of the Creative Commons Attribution license (http://creativecommons.org/licenses/by/4.0/). 